Article

\title{
Sustainable Development in the Economic, Environmental, and Social Fields of Ecuadorian Universities
}

\author{
Javier Alejandro Bermeo Pacheco ${ }^{1, *}$, María Mercedes Teijeiro-Álvarez ${ }^{2}$ and \\ María Teresa García-Álvarez 2 (D) \\ 1 Faculty of Business Administration, Universidad Técnica de Machala, Machala 170517, Ecuador \\ 2 Faculty of Economics, University of A Coruna, 15008 A Coruna, Spain; mercedes.teijeiro@udc.es (M.M.T.-Á.); \\ mtgarcia@udc.es (M.T.G.-Á.) \\ * Correspondence: jbermeo@utmachala.edu.ec; Tel.: +593-98714-0519
}

Received: 28 July 2020; Accepted: 4 September 2020; Published: 9 September 2020

check for updates

\begin{abstract}
This article considers universities as an important element to increase productivity and competitiveness, where sustainable development (SD) is a cornerstone aspect for their development because it promotes effective communication mechanisms. The aim of this research is to evaluate the management of category A and B universities in Ecuador, through the contents of their accountability reports. The method to be used is bibliographic, exploratory, analytical, and experimental, considering the indicators of the Global Reporting Initiative (GRI). The results show a lack of commitment from the analyzed higher education institutions when preparing accountability reports in terms of sustainability criteria. Additionally, the category in which each university is placed does not guarantee effective disclosure of information to the point that some category B universities have a higher percentage of revealed data than their A category peers. Similarly, the results also suggest proposing plans of action for policymakers to create standards for socially responsible annual reports to respond to the "triple bottom line" criteria approach, as well as establishing guidelines for the correct dissemination and disclosure of information. The originality of this work lies in analyzing the social responsibility practices in Ecuadorian universities by applying GRI indicators.
\end{abstract}

Keywords: sustainable development; higher education; social responsibility; global reporting initiative; accountability

\section{Introduction}

Sustainable development (SD) seeks a balance among economic growth, social well-being, and environmental well-being, which are pursued to meet the needs related to population growth and industrialization. The SD objectives try to put an end to problems on all sides with the firm intention of generating greater and better opportunities for progress in the world through the criteria of transparency in its actions. In addition, according to [1], it is essential to highlight that one of the basic problems to achieve environmental, social, and economic sustainability is autonomy from political powers in the academic government and the quality of the production and transfer of knowledge to society.

According to [2], universities are held socially responsible for an interdisciplinary approach which has them follow all sustainable development objectives that have been defined for all higher education institutions worldwide through the social, economic, and environmental dimensions. Therefore, all universities must promote sustainable-related competencies in which the previously mentioned dimensions are emphasized to achieve justice and social equity, which is why interdependence between a paradigm that favors educational inclusion and sustainable development in higher education must exist [3]. 
According to [4], Ecuador is facing challenges in the management of higher educational quality. This shows an imperative need to improve the internal quality management processes of all Ecuadorian universities to achieve superior standards, which must go hand in hand with government established standards for higher education that focus on quality, research, and a strong and productive relationship with society. In addition, the reality of each university must be regarded in terms of budget allocation established by law, which may have a negative impact on their level of organization, control, and performance [5].

The United Nations Educational, Scientific, and Cultural Organization (UNESCO) has established 17 objectives for sustainable development and is committed to their implementation between 2016 and 2030, and these objectives are part of an "integrated and indivisible set of global priorities. At the same time, it aims at considering and respecting the different national realities and priorities of each country. Therefore, without forgetting the global goals, the UN member states [6], "to eradicate poverty, protect the planet and ensure prosperity by following the 2030 Agenda for Sustainable Development". Said agenda comprises a political declaration along with 17 sustainable development goals, among which are:

Goal 4 Ensure inclusive, and equitable quality education and promote lifelong learning opportunities for all.

Goal 8 Promote sustained, inclusive, and sustainable economic growth, full and productive employment, and decent work for all.

Goal 16 Promote peaceful and inclusive societies for sustainable development, provide access to justice for all and build effective, accountable, and inclusive institutions at all levels.

Goal 17 Strengthen the means of implementation and revitalize the Global Partnership for Sustainable Development [7].

Universities currently adopt SD criteria, in their management model, which require establishing a transparency mechanism through more extensive accountability reports that meets the needs of different interest groups. The disclosure of information is also a sign of responsibility and commitment of the organization with its environment, becoming an element of support in the search for excellence. Therefore, institutions of higher education must ensure that the academic and administrative management goes according to the Global Reporting Initiative (GRI) indicator standards. According to [8], universities identify their sustainability-related pressures to contribute to their internal and global change processes that focus on sustainable development, which allows them to aim at enhancing the role of universities as sources of both strategic knowledge and educators of future generations.

The importance of implementing competences in sustainability in higher education is observed in the search for methodological scenarios that help to involve sustainable behaviors based on professional ethics. That is why universities must implement approaches that involve not only sustainability in the theoretical field but also methods that lead to the practice of such methods in real-life situations. All action fields covered by universities must be effectively and efficiently coordinated to involve methodological scenarios that lead to the proper implementation of sustainability [9].

Additionally, according to [10], sustainability has a group of 17 goals that must be developed and inserted into society. To ensure that the sustainable development goals are established and put into practice, universities must train their teachers, and therefore they can understand the importance of sustainability in all fields and help in its execution. This can be achieved by, for example, motivating students with extra credits and further academic recognition for implementing sustainability-related projects that meet the objectives of sustainable development, which would be a great way to contribute ethically and responsibly to society.

At present, the objectives of sustainable development have not been completely implemented by higher education institutions, despite being aware of their crucial importance, to the point that most universities are not implementing sustainability-related training programs [11]. Nowadays, 
sustainability has become more relevant than ever, which is prompting universities to search for methods that facilitate achieving such sustainability goals. A study carried out in the Cataluña International University proved that there were numerous visions, difficulties, and challenges regarding the concept of sustainable development. Therefore, as an educational institution, there is an obligation to pose challenges that motivate the university community to adhere to professional principles based on sustainable development [12].

However, the preparation of accountability reports in higher education institutions shows a lower level of development as compared with other sectors, which is clear when reviewing the GRI database. There are only 90 universities spread over Europe, Asia, North America, Africa, and Oceania that prepare accountability reports with the help of this tool.

Additionally, the GRI approach is being used in developed countries to find proper solutions and ideas that can be used in favor of effective and sustainable management. This work can be placed as the first line of research in its application in Ecuador, which will reveal the reality of Ecuadorian universities, from a triple bottom line approach, considering that such institutions must not be separated from the purposes, goals, challenges, and objectives outlined in the "National Development Plan 2017-2021: A Whole Life", which is the main regulatory instrument of the Decentralized National System of Participatory Planning (DNSPP) in Ecuador, whose major aim is to contribute to the progressive fulfillment of public policies [13].

Within that context, this work focuses on the state of sustainability reports in Ecuador, where several universities throughout the years have emerged because of the constant growth and development in the country, which has made it possible for them to stand out in the three main lines of action (academy, research, and connection). All Ecuadorian universities entered an institutional evaluation process of accreditation and categorization in 2002, which was in charge of the National Council for Evaluation and Accreditation (NCEA). Subsequently, in 2008, Constituent Mandate No. 14, empowered the NCEA to prepare a technical analysis on the level of institutional performance of all higher education institutions in Ecuador. As a result of their report, which was issued in November 2009, 68 universities were placed in the A, B, C, D, and E categories.

Then, in 2010, with the profound constitutional changes that took place in the higher education system along with the reform of the Organic Law of Higher Education of 2000, a new education quality evaluation government agency called the Council for the Evaluation, Accreditation and Quality Assurance of Higher Education (CEAQAHE) was created. This new agency evaluated 40 higher education institutions (HEIs), in 2013, under the following five criteria: academic, research, organization, infrastructure, and academic efficiency. After this new process of evaluation, the Ecuadorian universities were placed in one of four categories, i.e., A, B, C, and D and it was recommended that A, B, and C category institutions come up with an improvement plan, while the universities placed in the $D$ category were required to submit an institutional strengthening plan.

Afterwards, the last process of evaluation, accreditation, and recategorization of universities and polytechnic schools, carried out between the years 2015, 2016, and 2017 was carried out considering the following criteria: academic organization, research, engagement with the society, resources, infrastructure, and students. As of 2017, 33 universities in Ecuador have started the educational quality evaluation process, of which 15 are public and the remaining 18 are private institutions (see Table 1).

Table 1. Level of institutional performance of Ecuadorian universities from 2009 to 2017.

\begin{tabular}{ccccccc}
\hline Year & Category A & Category B & Category C & Category D & Category E & Total Universities \\
\hline 2009 & 11 & 9 & 13 & 9 & 26 & 68 \\
\hline 2013 & 3 & 17 & 14 & 6 & - & 40 \\
\hline 2017 & 6 & 27 & - & - & - & 33 \\
\hline
\end{tabular}

Source: Own elaboration based on the 2009 NCEA report and the 2013-2017 CEAQAHE report. 
Interestingly enough, the evaluation standards are those that justify the creation of the public value of several entities, including educational ones, which is based, according to [14], on regulatory sources such as the Constitution of Ecuador or the Higher Education Organic Law, among other accreditation and standard-setting agencies such as the CEAQAHE, which established new criteria for evaluating universities [15].

Therefore, the main objective of this work is to evaluate university management from an economic, social, and environmental perspective published in their accountability reports based on the indicators reflected in the GRI standards. This analysis is performed with all category A and B Ecuadorian universities, in the year 2017, in order to answer the following two crucial research questions:

Research Question 1 Do Ecuadorian universities prepare accountability reports under sustainability criteria? Research Question 2 What policies could be implemented to improve the elaboration of accountability reports?

To achieve our objective, this work presents a literature review in Section 2, the methodology is detailed in Section 3, the analysis of the results are explained in Section 4, a thorough discussion is included in Section 5, the conclusions are included in Section 6, and the implications and limitations of this study are detailed in Section 7.

\section{Literature Review}

\subsection{Sustainable Development}

According to [16], sustainable development is a way to try to merge different environmental perspectives with socioeconomic points of view in order to help people find proper solutions to problems that are affecting their lives so that they can secure a better future for all.

Additionally, [17] mentioned that sustainable development, as a concept, has been the subject of several attempts to define it under different criteria. However, the most relevant factor here is to understand that whatever criteria may go along with it, it must be clear enough to distinguish among goals, targets, indicators, or policies.

Moreover, a report published by [18] mentioned that sustainable development could be defined as progress that takes place without harming either our present or our future generations in order for them to cover all their needs by focusing on environmental protection, economic growth, and social equity. From an educational perspective, [19] stated that sustainable development helps organizations to think more clearly in terms of what is best to have a better and sustainable future for all humankind.

\subsection{Reporting: Accountability and Sustainability}

Accountability reporting in education, according to [20], is a process that helps fulfill responsibilities and reach any set goals within a given period of time. In order for this process to work properly, accountability reports must be accompanied by properly defined indicators that are crucial to determine their results. In that sense, [21] stated that said results must be considered to be a turning point that can help raise and broaden awareness of their impact on the society in social and economic terms. In addition, [22] stated that given the crucial role of higher education institutions in our modern world, the best way for them to be efficient, transparent, and environmentally responsible is to prepare accountability reports that follow a set of standards that can satisfy all stakeholders. All in all, [23] mentioned that accountability reports are a set of documents that are used to record, justify, and present the activities carried out by an organization to all stakeholders.

Additionally, [24] mentioned that sustainability reporting in higher education institutions must consider all social, economic, and environmental aspects in order to properly issue reports which must consider all stakeholders' interests. Therefore, the implementation of this kind of report must be adopted by universities as a managerial tool with proper connections to their institutional strategic objectives.

Public universities have started to experiment with sustainability-based reports, but these efforts are still limited by the multiple forms of management reports [25]. Nowadays, 
Integrated Reports (IR) generate public value and face accountability pressures. The purpose of IRs is to foster opportunities for innovation in socially responsible reporting in the public sector. From that perspective, sustainability reports help organizations to identify and set their sustainability policies to make it easier for them to manage their environmental practices (strategic plans, goal development, and performance measurement) by combining profitability with social responsibility [26]. In this sense, sustainability reports fulfill a dual function as follows:

1. Evaluating the institution's progress toward sustainability;

2. Being accountable for the efforts made by the institution in the economic, social, and environmental dimension before the different interest groups.

Among the available alternatives in this context, we have "the sustainability reporting" GRI standards characterized by being the first and most widely adopted global standards for sustainability reports [27], which are based on the following three classic dimensions of sustainability reporting:

Economic dimension. It affects the impact of the organization on the economic conditions of its stakeholders and economic systems at local, national, and international levels.

Environmental dimension It refers to an organization's impact on living and inert natural systems, including ecosystems, soil, air, and water. These environmental indicators cover performance concerning inflows (materials, energy, water) and outflows (emissions, discharges, and waste).

Social dimension. It is related to the impact of an organization's activities on the social systems in which it operates. Social performance indicators identify the key aspects of performance about labor issues, human rights, society, and product responsibility [28].

\subsection{The Triple Bottom Line and the GRI Approach}

In 1988, [29] worked on a framework to measure sustainability, and then came up with a model, called the triple bottom line (TBL). This framework focuses on conventional profit measures and also on environmental and social aspects, which makes it unique and highly effective in terms of reporting to all stakeholders, because an organization can clearly demonstrate its performance in every aspect and field.

The triple bottom line is a reference for an organization that claims to be sustainable in the social, economic, and environmental dimensions. When any of these dimensions is not respected, such organization will cease to be considered as sustainable [30]. Therefore, the TBL is considered to be a catalyst for a change in the performance of an organization because it enables the organization to be socially responsible and also highly efficient at whatever it does, which creates a strong link with the community and improves the organization's income potential [31].

Then, in 1997, the United Nations Environment Programme (UNEP) along with the Coalition for Environmentally Responsible Economies (CERES) and the Tellus Institute established the Global Reporting Initiative whose main goal was to develop a sustainability reporting framework to help all sorts of organizations to prepare and issue their accountability reports in a highly detailed fashion [32]. According to [33], the GRI works as a tool to measure the efficiency of an organization by reflecting upon the TBL pillars (economy, social equity, and environment) to, then, publish such results to the general public. The same author also mentioned this approach is highly practical in terms of simplifying and unifying conflicting accounting methodologies, which, at the same time, provides a format that is clear, useful, comparable and influential thanks to its transparent philosophy that is based on 11 principles, which are put in action through the application of 146 indicators.

The GRI standards are subdivided into indicators that analyze the information presented in the different dimensions in more detail (see Figure 1). Such indicators have a positive or negative value depending on their behavior. 


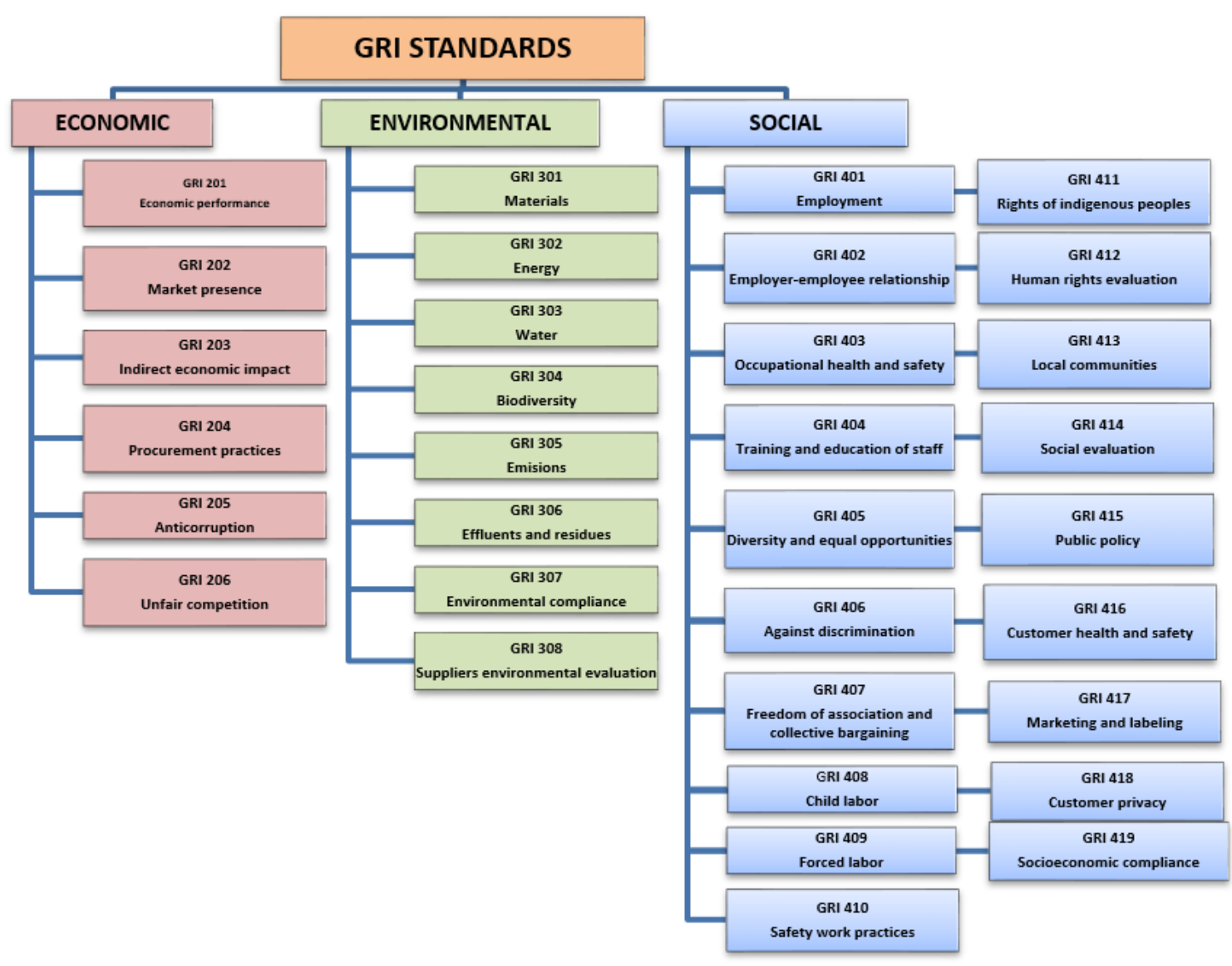

Figure 1. Global Reporting Initiative standards. Source: Own elaboration.

GRI reports have been continuously developed for 20 years and are among the best global practices for reporting in the three study axes. The aim pursued by the GRI organization is to increase the quality in preparing sustainability reports, which is also being done with financial reports, in terms of comparability, rigor, credibility, periodicity, and verifiability. In fact, $93 \%$ of the 250 largest corporations in the world issue their sustainability performance reports based on GRI standards, which means the GRI standards are one of the best mechanisms to report on the economic, social, and environmental dimensions of an organization [14].

According to [34], both the business sector and higher education institutions in Latin America continuously seek improvements in their organizations to mitigate negative impacts through the evaluation of their sustainability reports established by the GRI. This approach emerges to contribute to the economic, social, and environmental sustainability fields and functions as a tool that aids in the development of reports that, along with basic contents, sustainability contexts, precision, clarity, reliability, and the participation of all stakeholders, can help universities to achieve socially responsible management. Therefore, [35] mentioned that the application of the triple bottom line approach in higher education institutions is crucial because these instituitions have the social burden of providing society with socially, economically, and environmentally responsible professionals.

Additionally, it is worth mentioning that the university social responsibility (USR) is gaining increasing relevance because all stakeholders, more and more, demand for USR. This is why when organizing, planning strategies, and executing them, higher education universities have found, in sustainability reports, a great tool to evidence their ethics and transparency from the triple bottom line approach because, according to [36], the GRI approach assumes a fundamental role to assess and describe the level of social, economic, and environmental sustainability. Therefore, all sustainability 
reports issued by universities should reflect upon all those aspects to show their commitment to contribute to a sustainable future.

\subsection{Previous Studies on the Use of the GRI Approach}

A review of previous studies on the use of the GRI approach showed its importance in the business and educational sectors. Table 2 shows a summary of the reviewed articles found in different renowned bibliographic databases such as Scopus, Ebscohost, Scielo, which were published between 2012 and 2017.

Table 2. Recent studies on the use of the GRI approach and sustainability reports.

\begin{tabular}{|c|c|c|}
\hline \multicolumn{3}{|c|}{ Recent Studies on the Use of the GRI Approach and Sustainability Reports } \\
\hline Author(S) & Sample & Results \\
\hline Rosa et al. (2012) [37] & $\begin{array}{l}397 \mathrm{NH} \text { chain hotels in Europe, } \\
\text { America, and Africa Data } \\
\text { collection was performed in } 2010\end{array}$ & $\begin{array}{l}\text { They built a performance evaluation model called } \\
\text { Environmental Disclosure Evaluation Hotels (EDEH) under the } \\
\text { GRI3 indicators. The results show that the proposed model } \\
\text { helps to evaluate the performance of environmental information. }\end{array}$ \\
\hline Alcaraz-Quiles et al. (2014) [38] & 55 Spanish towns & $\begin{array}{l}\text { They analyzed the sustainability reports issued by the local } \\
\text { governments of the analyzed cities based on the GRI report. } \\
\text { The authors agree on the importance of GRI reports as a tool } \\
\text { for learning, management, and communication. }\end{array}$ \\
\hline Kumar et al. (2016) [39] & $\begin{array}{l}\text { Top } 10 \text { banks in India (based on } \\
\text { the size of their assets) Data } \\
\text { collection was performed based on } \\
\text { the fiscal year } 2016\end{array}$ & $\begin{array}{l}\text { The social responsibility metrics of the GRI-G4 guidelines } \\
\text { assigned to communication parameters were applied here. } \\
\text { The results show that the level of SR and disclosure is highly } \\
\text { inadequate, with only three banks publishing a detailed } \\
\text { sustainability report, and only two of them have adopted the } \\
\text { GRI-G4 framework. }\end{array}$ \\
\hline Romero et al. (2016) [40] & $\begin{array}{l}\text { Three higher education } \\
\text { institutions }\end{array}$ & $\begin{array}{l}\text { They applied randomization as a research approach to study the } \\
\text { sustainability reports of three higher education institutions in } \\
\text { Cali, Colombia and found that such institutions had very little } \\
\text { knowledge in terms of the GRI methodology, its application, } \\
\text { and advantages. }\end{array}$ \\
\hline Bilbao-Terol et al. (2017) [41] & $\begin{array}{l}8 \text { Spanish companies were chosen } \\
\text { for their relevance in the Spanish } \\
\text { stock market } \\
\text { Data gathering took place in } 2014 \text {. }\end{array}$ & $\begin{array}{l}\text { They developed a multi-criteria model according to the } \\
\text { hierarchical structure designed by the GRI. It was concluded } \\
\text { that, in general, the analyzed companies did not fully follow the } \\
\text { recommendations of the GRI Guide. Thus, companies only } \\
\text { focus on disclosing information about the number of employees, } \\
\text { type of contract, and working hours. }\end{array}$ \\
\hline Niemann et al. (2017) [42] & $\begin{array}{l}6 \text { European cities with at least } \\
100,000 \text { inhabitants belonging to } \\
\text { the Netherlands, Germany, } \\
\text { Ireland, and Switzerland } \\
\text { Data collection was carried out } \\
\text { over several years (2004-2015). }\end{array}$ & $\begin{array}{l}\text { They analyzed the sustainability reports issued by the local } \\
\text { governments of the analyzed cities based on the GRI report. } \\
\text { The authors agree on the importance of GRI reports as a tool for } \\
\text { learning, management, and communication. It was noticeable } \\
\text { that in the first years of preparing the sustainability reports, } \\
\text { more exhaustive information was shown however, the } \\
\text { "reporting fatigue" phenomenon is palpable, which is also } \\
\text { linked to the lack of financial help. }\end{array}$ \\
\hline Huerta and Gaete (2017) [43] & $\begin{array}{l}7650 \text { Institutions with } \\
\text { sustainability reports }\end{array}$ & $\begin{array}{l}\text { They determined social responsibility (SR), by providing } \\
\text { information on sustainability reports as a means of making the } \\
\text { activities that organizations carry out more visible; especially } \\
\text { those activities related to university social responsibility. }\end{array}$ \\
\hline Hervieux et al. (2017) [44] & $\begin{array}{l}14 \text { Signatories to the United } \\
\text { Nations' Principles for } \\
\text { Responsible Management } \\
\text { Education (PRME) }\end{array}$ & $\begin{array}{l}\text { After a careful analysis of Sharing in Progress (SIP) reports of } 14 \\
\text { signatories to the United Nations' Principles for Responsible } \\
\text { Management Education (PRME) by applying the GRI } \\
\text { sustainability reporting guidelines to identify any possibilities to } \\
\text { improve reporting processes, it was found that even the most } \\
\text { important nations inlcuded limited information on the social and } \\
\text { economic dimensions. However, in spite of the challenges faced } \\
\text { in PRIME implementantion, improving SIP reports is feasible. }\end{array}$ \\
\hline
\end{tabular}

Source: Own elaboration.

The GRI approach plays a very important role in higher education institutions (HEIs) since they are a model for society. Research related to sustainable development is essential because, thanks to it, universities assume, before society, their social connection and commitment to influence social policies. According to [45], sustainable development refers to the actions taken by humans to develop viable social communities from an economic and environmental point of view. In addition, [46] stated that 
evaluations based on USR indicators are very effective in decision making processes because they are easy to measure and are also easy to compare with other types of evaluation systems because of the ease of use of the GRI method, which is a clear sign which tells us that integrating sustainability in education and its curricula could transform education and lead the social change towards sustainability.

Within this context, it is important to mention that Ecuadorian public and private universities have not, until now, adopted the GRI methodology-based model for their sustainability reports that allow management reports to be measured in the economic, social, and environmental dimensions.

\section{Methodology}

The sample to be analyzed in this research consisted of public and private Ecuadorian universities that were categorized as either A or B in the year 2017. To have reliable data to support this research, the resolutions adopted by the Council for Evaluation, Accreditation and Quality Assurance of Higher Education (CEAQAHE) in 2017 were considered, since this was the organization that regulated institutional self-evaluation and also performed external quality evaluation processes of all HEIs. The final evaluation process reports of such universities are included in Table 3.

The method that helped us contrast the objective of this work was the application of information indexes. These are instruments designed to measure a series of elements that, when added up, offer a representative result of the level of information disclosure of the set of entities that make up the sample, according to the specific context for which such index was conceived [47]. The elaboration of an information index is performed in two phases as follows:

1. Selecting the informative elements that will be taken as a reference.

2. Establishing a weighed system that assesses the relative importance of each element included in the index.

In the present work, we constructed our analysis by using an unweighted dichotomous measure, because it focused on figuring out the occurrence or non-occurrence of certain events, having for this purpose $n$ observations to identify findings that allowed us to share recommendations to strengthen the construction of sustainable accountability. Thus, a dichotomous procedure is established according to which an element scores 1 when it contains information or 0 otherwise. The total result (RT), therefore, is the total of all the reported elements. Finally, the index value (TI) is calculated as the ratio between the provided information by each university (TR) and the maximum value that represents the disclosure of all elements considered (M). Consequently, the index value will be 0 and 1 [48]. It is worth mentioning that the following formulas are adaptations of the formulas used by the previously mentioned authors.

$$
R T=\sum_{i=1}^{m} d_{i}
$$

where $d_{i}=1$ if index $d_{i}$ is revealed and 0 otherwise, $m<n$.

$$
M=\sum_{i=1}^{n} d_{i}
$$

where $d_{i}=$ recommended disclosure item and $n=$ number of items to be disclosed by a given entity.

$$
T I=\frac{R T}{M}
$$

where $0 \leq T I \leq 1$.

The evaluation included 379 items related to sustainable development, of which 59 are associated with the economic dimension, 186 with the environmental dimension, and 134 with the social dimension. This is why the indicators were applied based on the information gathered from the accountability reports issued by Ecuadorian universities (see Table 3), whcih describes the sample of universities that 
were considered in the present research. The reports that enabled us to demonstrate the sustainability of an organization were those that used the GRI criteria, collected in the following three dimensions: economic, environmental, and social. Such reports are helpful to achieve a greater level of transparency in an organization and a better comparison of elements on a global scale [49].

Table 3. Universities with reliable data.

\begin{tabular}{|c|c|c|c|c|}
\hline No. & University & Category & CEAQAHE Resolution & Public/Private \\
\hline 1 & San Francisco de Quito University & $\mathrm{A}$ & 001-073-CEAACES-2013-01 & Private \\
\hline 2 & Espíritu Santo University & A & 396-CEAACES-SO-11-2016 & Private \\
\hline 3 & University of the Armed Forces (ESPE) & A & 388-CEAACES-SO-11-2016 & Private \\
\hline 4 & University of Cuenca & A & 386-CEAACES-SO-11-2016 & Public \\
\hline 5 & Littoral Polytechnic School (ESPOL) & A & 001-073-CEAACES-2013-03 & Public \\
\hline 6 & National Polytechnic School & $\mathrm{A}$ & 001-073-CEAACES-2013-02 & Public \\
\hline 7 & Indoamerica Technological University & B & 001-073-CEAACES-2013-04 & Private \\
\hline 8 & Equinoctial Technological University & B & 001-073-CEAACES-2013-10 & Private \\
\hline 9 & Technical Private University of Loja & B & 001-073-CEAACES-2013-24 & Private \\
\hline 10 & Technical State University of Quevedo & B & 001-073-CEAACES-2013-11 & Public \\
\hline 11 & Technical University of the North & B & 001-073-CEAACES-2013-13 & Public \\
\hline 12 & Technical University of Manabí & B & 397-CEAACES-SO-11-2016 & Public \\
\hline 13 & Technical University of Machala & B & 967-CEAACES-SO-28-2016 & Public \\
\hline 14 & Technical University of Ambato & B & 001-073-CEAACES-2013-17 & Public \\
\hline 15 & Salesian Polytechnic University & B & 001-073-CEAACES-2013-20 & Private \\
\hline 16 & State Polytechnic University of Carchi & B & 001-073-CEAACES-2013-46 & Public \\
\hline 17 & SEK International University & B & 001-073-CEAACES-2013-07 & Private \\
\hline 18 & National University of Loja & B & 001-073-CEAACES-2013-15 & Public \\
\hline 19 & Iberoamerican University of Ecuador & B & 001-073-CEAACES-2013-49 & Private \\
\hline 20 & State University of Milagro & B & 001-073-CEAACES-2013-08 & Public \\
\hline 21 & State University of the Amazon & B & 001-073-CEAACES-2013-47 & Public \\
\hline 22 & University of the Hemispheres & B & 001-073-CEAACES-2013-48 & Private \\
\hline 23 & University of the Americas & B & 390-CEAACES-SO-11-2016 & Private \\
\hline 24 & University of Guayaquil & B & 966-CEAACES-SO-28-2016 & Public \\
\hline 25 & Santiago de Guayaquil Catholic University & B & 001-073-CEAACES-2013-06 & Private \\
\hline 26 & Catholic University of Cuenca & B & 147-CEAACES-SE-13-2017 & Private \\
\hline 27 & Casa Grande University & B & 001-073-CEAACES-2013-09 & Private \\
\hline 28 & Pontifical Catholic University of Ecuador & B & 001-073-CEAACES-2013-22 & Private \\
\hline 29 & Higher Polytechnic School of Chimborazo & B & 001-073-CEAACES-2013-23 & Public \\
\hline 30 & International University of Ecuador & B & 394-CEAACES-SO-11-2016 & Private \\
\hline 31 & Central University of Ecuador & B & 001-073-CEAACES-2013-29 & Public \\
\hline 32 & University of Azuay & B & 001-073-CEAACES-2013-05 & Private \\
\hline 33 & $\begin{array}{c}\text { Technological University of Business of } \\
\text { Guayaquil }\end{array}$ & B & 001-073-CEAACES-2013-14 & Private \\
\hline
\end{tabular}

Source: Own elaboration.

The review of information gathered from reliable sources to find out about the reality of each Ecuadorian university was a process that relied on the reports issued by the control agency of educational quality in Ecuador, i.e., CEAQAHE and accountability reports of the year 2017, which were 
published on their respective websites, to identify their degree of compliance in relation to the GRI standards framework and their sustainability policies.

\section{Analysis of the Results}

The percentages shown in Table 4 correspond to the number of disclosures from public universities in Ecuador, whose reports were obtained from the accountability reports of 2017, through the application of the GRI approach. It is observed that the accountability reports issued by public universities are not prepared under any sustainability criteria. There are only two universities (Technical University of the North and Technical University of Machala) with the highest number of disclosures, 33 and 32, respectively, out of 379 items, while the other 13 universities remain at even lower levels. Among the public universities, the Technical University of the North has the highest number of disclosures, which shows that despite being a category B university, there is a great level of responsibility when writing its accountability report. These results show a significantly larger number of disclosures on the economic and social standards, which may have occurred because those are the most common aspects in terms of accountability reports.

Table 4. Number and percentage of GRI disclosures provided by public Ecuadorian universities.

\begin{tabular}{|c|c|c|c|c|c|c|}
\hline University & Category & $\begin{array}{l}\text { Economic } \\
\text { GRI }\end{array}$ & $\begin{array}{l}\text { Environmental } \\
\text { GRI }\end{array}$ & $\begin{array}{c}\text { Social } \\
\text { GRI }\end{array}$ & $\begin{array}{l}\text { Number of } \\
\text { Disclosures }\end{array}$ & $\begin{array}{l}\text { Disclosure } \\
\text { Percentage }\end{array}$ \\
\hline University of Cuenca & A & 12 & 0 & 11 & 23 & $6.1 \%$ \\
\hline National Polytechnic School & A & 11 & 0 & 10 & 21 & $5.5 \%$ \\
\hline Technical State University of Quevedo & B & 12 & 0 & 17 & 29 & $7.7 \%$ \\
\hline Technical University of Manabí & B & 12 & 2 & 15 & 29 & $7.7 \%$ \\
\hline Technical University of Machala & B & 10 & 0 & 22 & 32 & $8.4 \%$ \\
\hline Technical University of Ambato & B & 7 & 0 & 5 & 12 & $3.2 \%$ \\
\hline State Polytechnic University of Carchi & B & 8 & 1 & 13 & 22 & $5.8 \%$ \\
\hline University of Guayaquil & B & 11 & 2 & 8 & 21 & $5.5 \%$ \\
\hline $\begin{array}{l}\text { Higher Polytechnic School } \\
\text { of Chimborazo }\end{array}$ & $\mathrm{B}$ & 10 & 0 & 12 & 22 & $5.8 \%$ \\
\hline Central University of Ecuador & B & 7 & 1 & 13 & 21 & $5.5 \%$ \\
\hline
\end{tabular}

According to Table 5, the number of disclosures from private universities in Ecuador indicates that, by applying the GRI methodology, the University of Azuay and the Salesian Polytechnic University have the largest number of data revealed, i.e., 32 and 31, respectively, out of 379 items. Considering that these are category $B$ universities and that the accountability reports do not show pertinent evidence that contributes to these sustainability criteria, we can assert that it is probably due to the lack of detailed information. The number of GRI revelations on the economic, environmental, and social standards issued by private universities in Ecuador show that most Ecuadorian universities, public and private, limit their accountability reports to economic and social aspects despite promoting environmental awareness campaigns, which are simply ignored in their reports. 
Table 5. Number and percentage of disclosures provided by private Ecuadorian universities.

\begin{tabular}{|c|c|c|c|c|c|c|}
\hline University & Category & $\begin{array}{l}\text { Economic } \\
\text { GRI }\end{array}$ & $\begin{array}{l}\text { Environmental } \\
\text { GRI }\end{array}$ & $\begin{array}{c}\text { Social } \\
\text { GRI }\end{array}$ & $\begin{array}{l}\text { Number of } \\
\text { Disclosures }\end{array}$ & $\begin{array}{l}\text { Disclosure } \\
\text { Percentage }\end{array}$ \\
\hline Espíritu Santo University & A & 3 & 0 & 8 & 11 & $2.9 \%$ \\
\hline University of the Armed Forces "ESPE" & A & 7 & 1 & 1 & 9 & $2.4 \%$ \\
\hline San Francisco de Quito University & A & 9 & 1 & 4 & 14 & $3.7 \%$ \\
\hline Catholic University of Cuenca & B & 10 & 0 & 9 & 19 & $5 \%$ \\
\hline University of the Americas & B & 9 & 0 & 12 & 21 & $5.5 \%$ \\
\hline International University of Ecuador & B & 4 & 1 & 3 & 8 & $2.1 \%$ \\
\hline Casa Grande University & B & 7 & 1 & 8 & 16 & $4.2 \%$ \\
\hline $\begin{array}{l}\text { Santiago de Guayaquil Catholic } \\
\text { University }\end{array}$ & B & 10 & 1 & 9 & 20 & $5.3 \%$ \\
\hline Pontifical Catholic University of Ecuador & B & 4 & 2 & 8 & 14 & $3.7 \%$ \\
\hline Indoamerica Technological University & B & 9 & 0 & 11 & 20 & $5.3 \%$ \\
\hline SEK International Private University & B & 3 & 0 & 9 & 12 & $3.2 \%$ \\
\hline Salesian Polytechnic University & B & 12 & 2 & 17 & 31 & $8.2 \%$ \\
\hline University of Azuay & B & 3 & 11 & 18 & 32 & $8.4 \%$ \\
\hline Technical Private University of Loja & B & 9 & 0 & 12 & 21 & $5.5 \%$ \\
\hline $\begin{array}{l}\text { Technological University of } \\
\text { Business of Guayaquil }\end{array}$ & B & 0 & 0 & 0 & 0 & 0 \\
\hline Equator Technological University & B & 9 & 1 & 8 & 18 & $4.7 \%$ \\
\hline University of the Hemispheres & B & 5 & 0 & 9 & 14 & $3.7 \%$ \\
\hline Iberoamerican University of Ecuador & B & 7 & 0 & 7 & 14 & $3.7 \%$ \\
\hline
\end{tabular}

Unfortunately, the accountability reports issued by Ecuadorian universities differ from the application of these standards [50]. It can be observed in Tables 4 and 5 that public universities have a higher degree of compliance in their annual reports, although the difference is minimal. The compliance average in public universities is $6 \%$ as compared with $4.47 \%$ in the private ones.

To illustrate the information obtained from the accountability reports in question, a thorough analysis of the 33 analyzed Ecuadorian universities on the three assessment dimensions is presented below.

In the economic context, according to the analysis of the GRI 201 (economic performance), in the 201-1 (directly generated and distributed economic value), it can be observed that, out of the 33 analyzed universities, 24 of them, which represent $75 \%$ of them, such as the National Polytechnic School, Littoral Polytechnic School, University of Cuenca, University of the Armed Forces (ESPE), San Francisco de Quito University, Higher Polytechnic School of Chimborazo, Casa Grande University, and the Catholic University of Cuenca, among others show in the report the compliance of the budget execution of the year 2017. However, the following four universities do not show any evidence of this: Espíritu Santo University, University of Azuay, International University of Ecuador, and SEK International University; whereas the Pontifical Catholic University of Ecuador, Central University of Ecuador, University of the Hemispheres and the Technical University of the North do it incompletely.

In 201-2, 100\% of the universities do not register any financial implications and other risks or opportunities derived from climate change. Likewise, in 201-3 (benefit plan obligations and other retirement plans), $28 \%$ of the universities consider benefits to this group of interest, such as the Technical State University of Quevedo, Technical University of Manabí, Technical University of Machala, and the Higher Polytechnic School of Chimborazo, among others, whereas the remaining $72 \%$ do not mention any information regarding retirement plans.

Regarding 201-4 (financial assistance received from the government), higher education institutions are considered to receive financial assistance from the government, although the accountability report does not establish the balance of transactions between universities and the government (financial aid vs. paid taxes). The results obtained from this item are as follows: 18 universities, which correspond to 
$56 \%$, show evidence of received financial assistance; $41 \%$ of the universities partially register it; and the other $3 \%$ of the universities do not declare this information in their accountability reports, such as the case of the University of Azuay.

According to the research results of the GRI 202 (market presence), in 202-1 (initial standard wage category by gender ratio against the minimum local wage), $100 \%$ of universities do not register any of this information in detail. However, they address the issue of public policies for gender equality in their accountability reports, whereas, in 202-2, the reports do not show any information on the percentage of senior executives hired from the local community except for the Catholic University of Cuenca.

As for the study of GRI 203 (indirect economic impact), the analysis of 203-1 (investment in infrastructure and support services), the University of Azuay and the International University of Ecuador show evidence of investment in physical and technological infrastructure in their reports, which has contributed to the development of teaching and research. In contrast, the State University of the Amazon and the Technical University of Ambato do no, in any way, reflect information about this GRI, whereas the rest of universities, such as the University of the Americas, University of the Hemispheres, University of Guayaquil, Central University of Ecuador, Technical State University of Quevedo, Equinoctial Technological University, and the Indoamerica Technological University, among others partially comply with it. Regarding the study of GRI 203-2 (significant indirect economic impact), only the Technical University of the North shows relevant evidence in their accountability report of 2017.

According to the analysis of GRI 204 (acquisition practices), 69\% of the universities, such as the National Polytechnic School, University of Cuenca, University of the Armed Forces (ESPE), San Francisco de Quito University, Higher Polytechnic School of Chimborazo, and the Catholic University of Cuenca, among others, register in their accountability reports information on purchases of products and services made locally. However, $31 \%$ of the other universities, such as the National Polytechnic School, Espíritu Santo University, amd the Pontifical Catholic University of Ecuador, among others, do not show any evidence of the expense ratio on local suppliers.

According to the results obtained from the analysis of GRI 205 (anti-corruption), 100\% of the universities studied did not show any reports on acts of corruption in their accountability reports through a mandatory disciplinary regime, nor did they address training on anti-corruption policies and procedures.

Regarding GRI 206 (unfair competition), 97\% of the analyzed universities do not register legal actions related to unfair competition, monopolistic practices, or against free competition. However, only $3 \%$ of the studied universities, such as the case of the Technical Private University of Loja, slightly shows some kind of reference to actions taken against unfair competition.

With regards to the environmental axis, it is evident that the public universities in Ecuador, according to their management reports, do not comply with most of the indexes of this dimension, according to the analysis of GRI 301 (materials); in 301-1 (renewable and non-renewable used materials), it can be observed that, out of the 33 analyzed universities, only the National University of Loja reports data regarding this indicator in its report, whereas, in 301-2 (percentage of recycled inputs) and 301-3 (percentage of recovered products and packaging materials), the reports of the 33 universities do not show any data on these indicators, making their analysis an impossible task.

Regarding the GRI 302 (energy), in 302-1 (energy consumption within the organization), 302-2 (energy consumption outside the organization), 302-3 (energy intensity), 302-4 (reduction in energy consumption), and 302-5 (reduction in the energy requirements of products) none of the universities report information regarding these topics.

Regarding GRI 303 (water), in indexes 303-1 (water extraction by source), it can be observed that nine universities comply with one of the six standards, whose data correspond to the municipal water supplies or other public or private water services standard, where the reporting universities are as follows: Casa Grande University, Santiago de Guayaquil Catholic University, University of 
Guayaquil, State University of Milagro, National University of Loja, State Polytechnic University of Carchi, Salesian Polytechnic University, Technical University of Manabí, and the Technical University of the North. GRI 303-2 (sources of water significantly affected by extraction), the University of the Armed Forces (ESPE), Central University of Ecuador, University of Azuay, International University of Ecuador, and the Salesian Polytechnic University stand out because they reported one of the five standards proposed within this indicator; whereas, in GRI 303-3 (recycled and reused water), no university reports any data.

In GRI 304 (biodiversity), the indicator 304-1 (owned, leased, or managed centers of operations, located within or adjacent to protected areas or areas of high value for biodiversity outside protected areas), there is no data disclosed by any of the 33 universities. In 304-2 (significant impact of activities, products, and services on biodiversity), the Equinoctial Technological University, the Pontifical Catholic University of Ecuador, and the San Francisco de Quito University report in standard two and four. The rest of the analyzed universities do not report any data about these contents. In 304-3 (protected or restored habitats), only the University of Azuay stands out, reporting data on all the standards of this indicator. In 304-4 (species that appear on the IUCN Red List and on national conservation lists whose habitats are in areas affected by operations), the University of Azuay is yet again the only university that complies by providing with data for this standard.

Regarding GRI 305 (emissions), regarding 305-1 (GHG direct emissions), 305-2 (GHG indirect emissions when generating energy), 305-3 (after indirect GHG emissions), 305-4 (GHG emission intensity), 305-5 (GHG emission reduction), 305-6 (ozone-depleting substances emissions), 305-7 (nitrogen oxides (NOx), sulfur oxides ( $\mathrm{SOx}$ ) and other significant air emissions), was another indicator that should have been reported by the 33 analyzed universities. Unfortunately, since any data was revealed, such analysis is unfeasible.

In GRI 306 (effluents and residues), 306-1 (discharge of water depending on its quality and destination), 306-3 (significant spills), 306-4 (transport of hazardous waste), and 306-5 (bodies of water affected by wastewater discharges and surface run-offs), are completely ignored by the 33 analyzed universities in their management reports, whereas indicator 306-2 (residues by type and disposal method), which comprises 21 standards, was barely considered by the University of Guayaquil and the Technical University of Manabí, which only reported data on standard CI in their reports.

Regarding GRI 307 (environmental compliance), in 307-1 (infringement of environmental legislation and regulations), out of all the analyzed universities, only the University of Azuay provides data; however, it only included information of one out of the four indicators in its report.

In GRI 308 (environmental evaluation of suppliers), in 308-1 (new suppliers that have passed through evaluation and selection filters under environmental criteria) and 308-2 (negative environmental impact on the supply chain and taken measures), none of the analyzed universities complied with this standard in 2017.

From the social dimension, a deeper understanding of the realities that the analyzed universities experience can be achieved by examining their accountability reports through the analysis of GRI 19, which comprises this dimension.

GRI 401 (employment) reveals that 22 HEIs include new employees and their rotation in their reports, while 10 universities do not. The employability provided by Ecuadorian universities brings with it the advantage of various benefits, such as life insurance, health care, coverage for physical disability, and parental leave, among others, differentiating these benefits between full-time and part-time employees. The results show that, out of the 32 universities, only eight provide their employees with four to five job benefits and only the University of Azuay grants all the benefits specified in field 401-2, followed by the Technical University of Machala, which complies with everything except for the life insurance benefit.

Regarding parental leave, the findings indicate that only the Technical University of Machala reports that it grants parental leave to its employees but does not distinguish it by gender. The only university that fully complies with this requirement is the Higher Polytechnic School of Chimborazo. 
GRI 402 regulates the employer-employee relationship. The University of Azuay is the only university that promotes it by notifying its operational changes in advance, whereas the other 31 analyzed universities do not do so.

GRI 403, focuses on the occupational health and safety that all universities must follow. However, not all the analyzed universities have the good sense to do so. Only 10 universities, most of which are in the B category along with the University of Cuenca, have representation on health and safety committees. Although no university complies with statistical information on the types of accidents, frequency, or deaths, seven universities do comply with an accident record protocol.

The analysis of GRI 404 (training and education of staff), shows that a total of 24 HEIs report the percentages of performance evaluations applied to their employees, and only the Casa Grande University, Technical University of Manabí, Technical University of the North, and the Technical State University of Quevedo report on the average number of training and education hours spent per year by their staff. In other cases, only the number of teachers who are part of any training process is reported. In addition, only the Littoral Polytechnic School presents a program to improve the aptitude skills of their staff.

In GRI 405 (diversity and equal opportunities), the following categories are analyzed: gender, age, priority, and vulnerable groups are analyzed. Here, only the Catholic University of Cuenca and the Technical University of Machala comply with reporting the gender of the members of their regulatory bodies, while the other 32 analyzed universities do not even pay attention to this point. Regarding the occupational category related to employee age, only five universities reported suitable information, whereas the other 27 universities ignored this category. Additionally, none of the analyzed universities reported any information related to the minority or vulnerable groups indicator, such as information on the minimum wage for men and women.

GRI 406 (legal rights protection against discrimination) is also regulated in the Ecuadorian legal framework, which is why Ecuadorian universities must report this in their accountability reports yet most of them do not do it despite its compulsoriness. Thus, out of the 32 analyzed universities in this study, only the National Polytechnic School, Salesian Polytechnic University, Technical University of Ambato, and the Technical University of Machala have implemented action plans to repair any damages in case discrimination issues that have emerged, although none of the mentioned universities have reported any discriminatory situations.

Regarding GRI 407 (freedom of association and collective bargaining), none of the 33 analyzed HEIs show any information about operations and supply management in their accountability reports, which could mean that their staff freedom of association and collective bargaining right could be at risk. GRI 408 (child labor types) and GRI 409 (forced or compulsory labor) are in the same risky position as GRI 407 , since none of the analyzed universities provide any information on these standards in their reports.

When inquired about GRI 410 (safety work practices) and security staff who are properly trained on human rights policies and their implementation in the labor field and whether that knowledge is shared with other organizations, the International University of Ecuador and Technical University of the North effectively inform about this in their accountability reports. The Technical University of Machala also complies with this standard but fails at sharing their knowledge with others.

Concerning GRI 411 (rights of indigenous peoples), it can be observed that within the Ecuadorian constitutional framework, the rights of indigenous peoples are effectively recognized and, in that sense, all HEIs are forced to report any case of violation of their rights. Very surprisingly, none of the 33 analyzed universities comply with reporting in this regard, except for the University of Azuay, which contemplates the application of plans to mend their rights if need be.

GRI 412 responds to the existence of an operational field to review or evaluate the impact on human rights. Only the University of Cuenca and the University of Azuay comply with this standard, whereas the other 30 analyzed HEIs failed to do so to the point that they do not even offer their staff any kind of training on human rights policies or procedures, and they do not have employee training 
in human rights policies, or significant investment agreements, or contracts with clauses that include inherent human rights clauses.

GRI 413 refers to local communities, which focuses on operations with the participation of local communities, impact evaluations, and development programs. Among all the analyzed universities, only 18 universities worked with four of the eight standards, such as the evaluation of their social and environmental impact or the publication of such results. The Casa Grande University, Santiago de Guayaquil Catholic University, State University of the Amazon, National University of Loja, SEK International University, and the State Polytechnic University of Carchi, which are in the B category positively stand out from the rest of universities. In addition, 28 universities comply with the creation of community development programs that focused on their particular needs. Among the universities, there are none that report anything in terms of the existence of committees, works council, or complaint procedures in their local communities or significantly (real or potential) negative impact operations.

In GRI 414 (social evaluation of suppliers), the Littoral Polytechnic School is the only university that includes in its accountability report of 2017, the percentage of newly evaluated and selected suppliers according to social criteria, whereas the other remaining 31 universities fail to report it.

In GRI 415 (public policy), the Technical Private University of Loja is the only university that reports a monetary contribution to political parties or representatives but without disclosing any details of such contributions. The remaining 31 analyzed universities do not even include this standard in their accountability report.

Regarding GRI 416 (customer health and safety), higher education institutions must include in their accountability reports the impact of their products on customers. This objective is achieved by 11 universities, of which only one belongs to the A category, which is the National Polytechnic School but does not define any non-compliance cases related to this standard.

In GRI 417, regarding marketing and labeling, the University of Azuay complies with four of the five required indicators of this standard. In this regard, 24 universities report the origin of their products, four universities detail the content of their products, and only one university gives details on how to safely use and dispose of their products along with their social and environmental impact. However, there is no evidence of a violation of any of these indicators related to the information, marketing, and labeling of products.

GRI 418 (customer privacy) and GRI 419 (socioeconomic compliance) represent another factor that should have been reported by the 33 analyzed universities. However, considering the lack of data on these aspects, such analysis is impossible to perform.

From the obtained results, it can be finally stated that the Ecuadorian universities are highly focused on reporting socioeconomic data to be transparent in all their spending and investment processes, as well as fulfilling their obligations towards their teaching and administrative staff. However, $51.5 \%$ of the analyzed universities do not include any data related to the environmental dimension in their accountability reports, which may be an indicator of the lack of interest towards the importance of reporting on this dimension to all groups of interest.

\section{Discussion}

In this section, a comprehensive analysis of the results is performed in order to find answers to our two research questions. First, this research project exceeds the limits of this study by considering what can be learned after evaluating the accountability reports of Ecuadorian universities when applying the GRI methodology and their indicators. [51] mentioned that the GRI approach is one of the best initiatives that has been adopted by several countries, which is why the focus of this study is to evaluate the accountability reports of category A and B Ecuadorian universities under sustainability criteria.

Additionally, it is worth mentioning that the triple bottom line approach goes hand in hand with the 17 objectives of sustainable development defined by the United Nations, which are crucial to integrate justice, development, and safety with economic, social, and environmental sustainability. 
From that perspective, the accountability reports issued by the analyzed Ecuadorian universities are a vital source of information that can function as the basis for further analysis [52].

Another point worth mentioning is the fact that according to Article 91 of the Council of Citizen Participation and Social Control regulation, all the people must have complete access to information in terms of public management and accountability reports. In addition, these reports must be evaluated through 59 economic indicators, 186 environmental indicators, and 134 economic indicators whose main goal is to reveal findings that can be used as feedback to prepare future reports.

Therefore, to answer our first research question, we must first point out the fact that most universities comply with the economic performance dimension with examples such as GRI 201 or 204, in which almost all universities successfully report information, whereas in other indicators such as GRI 202, none of the analyzed universities disclosed any information, or GRI 203 which is partially disclosed by less than half of the universities in question. Then, there is the environmental dimension, which was mostly ignored by all the universities analyzed in this study with examples such as GRI 301 that was disclosed by only one university or GRI 302, 304, 305, 306, and 307 that were completely ignored, or the example of GRI 303 that was disclosed by only nine universities.

Additionally, regarding the social dimension, GRI 401 and 417 were disclosed by most universities, whereas GRI 417 was disclosed by more than half of the analyzed institutions. Then, we have GRI 402, 403, 404, 405, 406, 414, and 415, which were disclosed by less than half of all the HEIs, whereas the remaining GRI indicators $(407,409,410,411,418$, and 419) were not disclosed at all.

It is quite remarkable that category B universities prepare their accountability reports taking into consideration more sustainability indicators than category A institutions, which proves, yet again, that belonging to a certain university category does not mean they are more or less responsible in terms of sustainability policies. Interestingly enough, the same situation happens when comparing private and public universities, with the public universities being more respectful of the GRI standards. This tells us that university social responsibility has got nothing to do with categories or types of universities, but rather with the governmental entities that regulate them through their policies, which is why the Ecuadorian government must be socially and sustainably responsible in all its actions, so that all the objectives established by the UNESCO in the agenda for sustainable development can be reached by 2030 .

Consequently, it must be stated that Ecuadorian universities do not prepare their accountability reports under sustainability criteria, which was easy to figure out after analyzing the results of this study which show that the focus of such reports lies almost exclusively on the economic and social dimensions, putting the environmental dimension aside.

The discussion above takes us to our second research question, to think of possible policies that could help to improve the elaboration of accountability reports. In that regard, [53] mentions that environmental policies should be defined as a priority to have a deeper impact on socioeconomic policies. This means that all public institutions that can work with the GRI approach should be informed about all these policies so that they can start preparing their future accountability reports under such standards.

The Ministry of Finance should implement a policy that forces all universities, public and private, to prepare their accountability reports under very specific guidelines and regulations that stick to the economic dimension of the GRI standards, so they can properly report on their economic performance, market presence, indirect economic impact, procurement practices, anticorruption practices, and anti-unfair competition measurements. Sticking to such standards would definitely help universities to become more efficient in economic terms and help them improve their income potential.

Likewise, the Ministry of Labor should also legally require all universities to prepare their accountability reports by focusing on the social dimension of the GRI standards, so that information gets properly disclosed on all its indicators, such as employment, employer-employee relationship, occupation health and safety, or training and education of staff, among others. This requirement would 
push all universities to come up with better strategies to prepare their reports and also with proper actions that can benefit all stakeholders throughout all that process.

Additionally, the Ministry of the Environment should demand all universities to work on their accountability reports in such a way that all GRI standards from the environmental dimension are fully respected. Their report must disclose information on materials used, energy and water consumption, or biodiversity, among others. This requirement would be the bridge that could take universities to the path of real sustainability.

In addition, the Council of Citizen Participation and Social Control should establish regulations and guidelines for the correct dissemination and disclosure of the data included in their accountability reports to contribute to the 17 goals of sustainable development established by the UN, especially Goal 16 that states that we should strive for a society with institutions that are effective, accountable, and inclusive in order to achieve sustainable development. This would help the community be well informed about how all Ecuadorian universities assume their social role before society.

Moreover, the Council for the Evaluation, Accreditation and Quality Assurance of Higher Education should create specific regulatory commissions to work with different types of universities, thus, a better and more "individualized" attention could be given to both public and private universities because, as we have seen above, Ecuadorian universities tend to not stick to all GRI standards as strictly as they should. These commissions should be created in order to help universities comply with all the GRI standards under their guidance and control.

Finally, all the guidelines and regulations issued by the ministries and councils abovementioned should be socialized first with all the Ecuadorian universities. Once they all are familiar with them, they should be ready to prepare their next accountability reports with an improved and, mandatory structure.

\section{Conclusions}

This work represents a pioneering initiative in evaluating the accountability of Ecuadorian universities from a sustainability perspective. The originality of this project lies on the fact that it carries out a thorough analysis of all the accountability reports issued by several public and private Ecuadorian universities, which are placed in the A and B categories, respectively, along with a deep examination of the economic, social, and environmental aspects included in such reports, which were issued in the year 2017. The objective here is to evaluate their socially responsible and sustainable behavior through the application of the GRI methodology, which is a tool that is beginning to be used by universities in several developed countries. Therefore, this would be the very first time this kind of methodology is applied in Ecuador to explore different sustainability practices from that perspective. Next, the main conclusions and reflections of this research project are detailed.

The results have shown that the level of commitment in the elaboration of accountability reports issued by the analyzed universities does not match the category in which each one of them is placed, as it was found that category B universities are the universities that have the highest percentage of data disclosure, such as the Technical University of the North and the Technical University of Machala, which are public institutions, with $8.7 \%$ and $8.4 \%$, respectively. Likewise, the University of Azuay and the Salesian Polytechnic University, which are private universities, had $8.4 \%$ and $8.2 \%$ data disclosure, respectively. This confirms that $72.73 \%$ of the category B universities are above the data disclosure percentages of those issued by category A universities. The degree of information provided by public universities is higher than that of private universities, with a GRI indicator degree of compliance of $6.03 \%$ for public universities and $4.67 \%$ for private universities. This shows that public universities have a greater socially responsible vision when preparing their accountability reports, which is reflected by a wider range of information disclosed in terms of the three evaluation dimensions of the GRI standard methodology.

The evaluation of information included in the accountability reports issued by the analyzed Ecuadorian universities shows a lack of sustainable vision, which is why the compliance rate, according to the GRI methodology, is below $9 \%$ in all the studied universities. In that sense, the social 
and economic aspects are the ones with the highest levels of disclosed information. Interestingly enough, the social aspect is highly emphasized because of the existing obligation of preparing reports to demonstrate compliance with all regulations issued by the Organic Law on Public Service, the Labor Code, or agreements issued by the Ministry of Labor, among others, regarding salaries, hiring, rotation, training, sanctions, and staff health and safety. A similar situation happens with the economic dimension because the finance department of every university is held responsible for the elaboration of their fiscal year-end reports in compliance with the Ministry of Finance and the Superintendency of Companies standards to justify the execution of the annual budget and transparent management of resources and investments. Regarding the environmental aspect, the reality differs completely from the two previous aspects, because $51 \%$ of the analyzed universities do not disclose any environment-related information in their accountability reports, which is caused by a legal accreditation model that focuses almost exclusively on bureaucracy, formalities, and excessive paperwork that happens not only in Ecuador but all over the Latin American continent [54]. It is worth noticing that the Ministry of the Environment is the government entity in charge of issuing and regulating national environmental policies; however, the lack of said regulations for higher education institutions to prepare their annual accountability reports makes it an impossible task to report on anything environment related. This proves there is a tendency to favor financial data in all accountability reports issued by universities over any other aspects or standards, even though the triple bottom line approach emphasizes that the environmental dimension is as important as any other dimension because it helps people develop a sense of rational environmental awareness [55].

Nonetheless, many of the analyzed universities probably do more than they report, which may happen because they are limited by the accountability report compliance regulations stated in article 9 (report content). Therefore, the Council of Citizen Participation and Social Control must change the report content guidelines so that these reports can go hand in hand with the GRI standard model to expand the disclosure requirements. Therefore, more information could be provided to all the different stakeholders and better decisions could be taken in the interest of strengthening the development of all Ecuadorian universities.

Higher education institutions have the great responsibility of contributing to the construction of a more sustainable world; hence, their social commitment should be an example to be followed by everyone to potentially cause a direct and positive impact on the economic, cultural, scientific, and social development of society. Therefore, it is crucially important for universities to become a point of reference in terms of sustainable development.

\section{Implications and Limitations}

Considering that this study has worked with category A and B Ecuadorian universities, it would be ideal to expand upon the findings of this work by analyzing more universities in future studies which could also consider a longer time frame beyond the year 2017.

Since this study is a pioneer in this field by considering the GRI approach as a tool to analyze how Ecuadorian universities prepare their accountability reports, an obvious limitation of this work is its statistical approach. In that regard, a longitudinal analysis would help explore the development of higher education institutions' accountability reports beyond 2017. This fact implies that a comparative study of the performance of universities from 2017 to 2020 should be carried out in the near future to study the progress and growth of Ecuadorian universities in the economic, social, and environmental dimensions.

Author Contributions: Conceptualization, M.M.T.-Á., M.T.G.-Á. and J.A.B.P.; methodology, M.M.T.-Á., M.T.G.-Á. and J.A.B.P.; investigation, M.M.T.-Á., M.T.G.-Á. and J.A.B.P.; writing, original draft preparation, J.A.B.P.; writing, review, and editing, M.M.T.-Á., M.T.G.-Á. and J.A.B.P. All authors have read and agreed to the published version of the manuscript.

Funding: This research received no external funding.

Conflicts of Interest: The authors declare no conflict of interest. 


\section{References}

1. He, M.; Pei, L.; Ran, K.; Song, T. Analysis on the Higher Education Sustainability in China Based on the Comparison between Universities in China and America. Sustainability 2020, 12, 573. [CrossRef]

2. Alcalá, M.; Gutiérrez, J. Sustainable Development as a Pedagogical Challenge for the 21st Century University. Rev. Andal. Cienc. Soc. 2020, 19, 59-80.

3. Litzner, L.; Rieß, W. Education for Sustainable Development in the Context of Higher Education in Bolivia. Perceptions of University Professors. Teoría Educ. Rev. Univ. 2019, 31. [CrossRef]

4. Orozco, E.; Jaya, A.; Ramos, F.; Guerra, R. Retos a La Gestión de La Calidad En Las Instituciones de Educación Superior En Ecuador. Educ. Médica Super. 2020, 32, 1-14.

5. Cárdenas, A. Calidad En La Gestión Universitaria Ecuatoriana: Una Búsqueda Latente de Eficiencia Educativa. Multiciencias 2016, 16, 194-201.

6. Sanahuja, J.; Tezanos, S. Del milenio a la sostenibilidad: Retos y perspectivas de la Agenda 2030 para el desarrollo sostenible. Politica Soc. 2016, 54, 533-555. [CrossRef]

7. Naciones Unidas. Educación Para los Objetivos de Desarrollo Sostenible. Available online: https://www.un. org/sustainabledevelopment/es/objetivos-de-desarrollo-sostenible/ (accessed on 2 June 2020).

8. Lattu, A.; Cai, Y. Tensions in the Sustainability of Higher Education-The Case of Finnish Universities. Sustainability 2020, 12, 1941. [CrossRef]

9. Albareda, S.; Gonzalvo, M. Competencias Genéricas En Sostenibilidad En La Educación Superior. Revisión y Compilación. Rev. Comun. SEECI 2013, 15. [CrossRef]

10. Valderrama, R.; Alcántara, L.; Sánchez, F.; Caballero, D.; Serrate, S.; Gil, D.; Vidal, S.; Miñano, R. ¿Forma En Sostenibilidad El Sistema Universitario Español? Visión Del Alumnado de Cuatro Universidades. Educ. XX1 2020, 23. [CrossRef]

11. Aleixo, A.M.; Azeiteiro Ulisses, M. Leal Susana. Are the Sustainable Development Goals Being Implemented in the Portuguese Higher Education Formative Offer? Int. J. Sustain. High. Educ. 2020, 21, 336-352. [CrossRef]

12. Albareda-Tiana, S.; Vidal-Raméntol, S.; Fernández-Morilla, M. Implementing the Sustainable Development Goals at University Level. Int. J. Sustain. High. Educ. 2018, 19, 473-497. [CrossRef]

13. Secretaría Técnica Planifica Ecuador. Plan Nacional de Desarrollo 2017-2021 Toda una Vida. Available online: https:/www.planificacion.gob.ec/plan-nacional-de-desarrollo-2017-2021-toda-una-vida/ (accessed on 5 June 2020).

14. Traxler, A.; Greiling, D.; Hebesberger, H. GRI Sustainability Reporting by INGOs: A Way Forward for Improving Accountability? VOLUNTAS: Int. J. Volunt. Nonprofit Organ. 2018, 5, 1-17. [CrossRef]

15. Traxler, A.; Greiling, D. Sustainable Public Value Reporting of Electric Utilities. Sustain. Public Value Rep. 2018, 5, 103-121. [CrossRef]

16. Hopwood, B.; Mellor, M.; O’Brien, G. Sustainable Development: Mapping Different Approaches. Sustain. Dev. 2005, 13, 38-52. [CrossRef]

17. Parris, T.; Kates, R. Characterizing and Measuring Sustainable Development. Annu. Rev. Environ. Resour. 2003, 28, 559-586. [CrossRef]

18. World Commission on Environment and Development. Our Common Future; Oxford University Press: Oxford, UK, 1987.

19. UNESCO. Shaping the Future We Want: UN Decade of Education for Sustainable Development; Final Report; UNESCO: Paris, France, 2014.

20. Mazariegos, P.; Sánchez, F. La Rendición de Cuentas En Establecimientos Educativos de Guatemala. Rev. Electrónica Investig. Docencia 2019, 21. [CrossRef]

21. Arowoshegbe, A.; Emmanuel, U.; Gina, A. Sustainability and Triple Bottom Line: An Overview of Two Interrelated Concepts. Igbinedion Univ. J. Account. 2016, 2, 88-126.

22. Rymarzak, M.; Marmot, A. Higher Education Estate Data Accountability: The Contrasting Experience of UK and Poland. High. Educ. Policy 2020, 33, 179-194. [CrossRef]

23. Parcerisa, L.; Falabella, A. La Consolidación Del Estado Evaluador a Través de Políticas de Rendición de Cuentas. Educ. Policy Anal. Arch. Arch. Analíticos Políticas Educ. 2017, 25, 1-24.

24. Brusca, I.; Labrador, M.; Larran, M. The Challenge of Sustainability and Integrated Reporting at Universities: A Case Study. J. Clean. Prod. 2018, 188, 347-354. [CrossRef] 
25. Mauro, C.; Cinquini, L.; Simonini, E.; Tenucci, A. Moving from Social and Sustainability Reporting to Integrated Reporting: Exploring the Potential of Italian Public-Funded Universities' Reports. Sustainability 2020, 12, 3172. [CrossRef]

26. Gónen, S.; Solak, B. An Emprical Study for Determining the Compliance of Sustainability Reports Published in Turkey with Standards Published by Global Reporting Initiative (GRI). World Account. Sci. 2016, 18, 393-420.

27. De Oliviera, E.; Rodríguez, R.; Teixeira, U. Public Sector (Un)Sustainability: A Study of GRI Adherence and Sustainability Reporting Disclosure Standards in Public Institutions and State-Owned Companies of the Public Agency Sector. Cuad. Contab. 2020, 20, 1-18. [CrossRef]

28. Vázquez, I.; Tapia-Castillo, D.; Díaz, D. La Sustentabilidad En Las Instituciones de Educación Superior. XIKUA Boletín Científico Esc. Super. Tlahuelilpan 2019, 7, 40-47. [CrossRef]

29. Elkington, J. Accounting for the Triple Bottom Line. Meas. Bus. Excell. 1998, 2, 18-22. [CrossRef]

30. Cuevas, R.; Rodriguez, R. Responsabilidad Social y Ética Profesional En La Gestión de La Administración Pública y Empresarial. Pensam. Gestión 2017, 42, 1-25. [CrossRef]

31. Gaete, R. La Responsabilidad Social Universitaria En La Identidad Corporativa de Las Universidades Chilenas Un Análisis de Contenido. Doc. Aportes Adm. Pública Gestión Estata 2016, 16, 43-74.

32. Global Reporting Initiative. GRI's History. Available online: https:/www.globalreporting.org/information/ about-gri/gri-history/Pages/GRI\%27s\%20history.aspx (accessed on 29 August 2020).

33. Stenzel, P. Sustainability, the Triple Bottom Line, and the Global Reporting Initiative. Glob. Edge Bus. Rev. 2010, 4, 1-2.

34. Acevedo, J.; Rafael, P. Evolución Del Reporteo En Sostenibilidad En Latinoamérica Bajo Los Lineamientos Del GRI (Global Reporting Initiative). Signos 2019, 11. [CrossRef]

35. Aldeanueva, I.; Arrabal, G. Communication and Measurement of the University Social Responsibility: Social Networks and Indicator Proposal. Rev. Digit. Investig. Docencia Univ. 2018, 12. [CrossRef]

36. Rodríguez, L.; Ríos, L. Evaluation of Sustainability Using GRI Methodology. Dimens. Empresarial 2016, 14. [CrossRef]

37. Rosa, F.; Lunkes, R.; Pfitscher, E.D.; Felji, V.M.R.; Soler, C.C. Contabilidad Medioambiental En España: Proceso Estructurado de Revisión y Análisis Teórico Referencial. Contab. Neg. 2012, 7, $23-48$.

38. Alcaraz-Quiles, F.J.; Navarro-Galera, A.; Ortiz-Rodríguez, D. Factors Influencing the Transparency of Sustainability Information in Regional Governments: An Empirical Study. J. Clean. Prod. 2014, 82, 179-191. [CrossRef]

39. Kumar, R.; Choudhury, D.; Bhargava, K. Determination of Blast-Induced Ground Vibration Equations for Rocks Using Mechanical and Geological Properties. J. Rock Mech. Geotech. Eng. 2016, 8, 341-349. [CrossRef]

40. Romero, W.; Ocampo, A.; Ríos, J. Apropiación de Los Informes de Responsabilidad Social En Las Instituciones de Educación Superior En La Ciudad de Cali. Contexto 2016, 5. [CrossRef]

41. Bilbao-Terol, A.; Álvarez-Otero, S.; Bilbao-Terol, C.; Cañal-Fernández, V. Hedonic Evaluation of the SRI Label of Mutual Funds Using Matching Methodology. Int. Rev. Financ. Anal. 2017, 52, 213-227. [CrossRef]

42. Niemann, L.; Hoppe, T.; Coenen, F. On the Benefits of Using Process Indicators in Local Sustainability Monitoring: Lessons from a Dutch Municipal Ranking (1999-2014). Environ. Policy Gov. 2017, 27, $28-44$. [CrossRef]

43. Huerta, P.; Gaete, H. Responsabilidad social universitaria a través de los reportes de sostenibilidad del Global Reporting Initiative: Experiencia de una universidad pública. Rev. Iberoam. Educ. Super. 2017, 8, 120-137.

44. Hervieux, C.; McKee, M.; Driscoll, C. Room for Improvement: Using GRI Principles to Explore Potential for Advancing PRME SIP Reporting. Int. J. Manag. Educ. 2017, 15, 219-237. [CrossRef]

45. Simona, S.; Stoian, C.; Gherheș, V. The Concept of Sustainability in the Romanian Top Universities' Strategic Plans. Sustainability 2020, 12, 2757. [CrossRef]

46. Guijarro, C.; Gomera, A.; Antúnez, M. Propuesta de Indicadores de La Responsabilidad Social Universitaria Conforme a La Guía G4 Del GRI: El Caso de La Universidad de Córdoba. CIRIEC-España Rev. Econ. Pública Soc. Coop. 2016, 87, 103.

47. Coy, D.; Tower, G.; Dixon, K. Quantifying the Quality of Tertiary Education Annual Reports. Account. Financ. 1993, 33, 121-129. [CrossRef]

48. Moneva, J.; Vallespín, E. Universidad y desarrollo sostenible: Análisis de la rendición de cuentas de las universidades públicas desde un enfoque de responsabilidad social. Rev. Iberoam. Contab. Gestión X 2012, 10, 1-18. 
49. Lorenzo, L.; Larramendy, E.; Tellechea, P. Avances en la exposición contable de CoPs y memorias GRI. PECVNIA Rev. Fac. Cienc. Económicas Empresariales 2012, 20, 109-128. [CrossRef]

50. Bilbao-Terol, A.; Arenas-Parra, M.; Cañal-Fernández, V.; Obam-Eyang, P.N. Multi-Criteria Analysis of the GRI Sustainability Reports: An Application to Socially Responsible Investment. J. Oper. Res. Soc. 2018, 69, 1576-1598. [CrossRef]

51. Sepúlveda, Y.; Valero, G. Un Análisis de Los Estudios Acerca de Las Memorias de Sostenibilidad En Latinoamérica. Contab. Neg. 2018, 13. [CrossRef]

52. Pérez, M.; Acosta, I.; Acurero, M. Categorías de Análisis Sobre La Sostenibilidad Una Propuesta Teorética y Contextualizada Para El Sector Empresarial. Económicas CUC 2020, 41. [CrossRef]

53. Borrell, M. Políticas Públicas (Políticas Sociales) y Medioambiente En La U.E. Obs. Medioambient. 2004, 7, 55-74.

54. Berdugo, N.; Montaño, W. La Educación Ambiental En Las Instituciones de Educación Superior Públicas Acreditadas En Colombia. Rev. Científica Gen. José María Córdova 2017, 15, 127-136. [CrossRef]

55. Martínez, J.; Tobón, S.; Sandoval, A. Problemáticas relacionadas con la acreditación de la calidad de la educación superior en América Latina. Innovación Educ. (México DF) 2017, 17, 79-96.

(C) 2020 by the authors. Licensee MDPI, Basel, Switzerland. This article is an open access article distributed under the terms and conditions of the Creative Commons Attribution (CC BY) license (http://creativecommons.org/licenses/by/4.0/). 